\title{
NOTES
}

\section{ACCELERATION CLAUSES IN TIME PAPER UNDER THE NIL AND THE UNIFORM COMMERCIAL CODE}

Article III of the Uniform Commercial Code, ${ }^{1}$ dealing with Commercial Paper, has made numerous changes in the law of negotiable instruments. $^{2}$ This Note is concerned with an examination of some of those changes stemming from the provision which reads, in its final form: ${ }^{3}$

"(1) An instrument is payable at a definite time if by its terms it is payable

“. . .

"(c) at a definite time subject to any acceleration. . . ."

Essentially this means that no acceleration clause destroys the negotiability of commercial paper under the new Code because of lack of time certainty. ${ }^{4}$ Whether or not this is a wise provision in light of current commercial practices, it is undeniably iconoclastic.

The history of the many types of clauses which mature a promissory note earlier than the fixed date stated in the note is at least as confusing as the current state of the law regarding them.5 This confusion is due, perhaps, to the inability of courts to resolve the conflict between the interests of the maker and the holder within the framework of the Negotiable Instruments Law. The maker (debtor) of a time note, unlike the maker of a demand note, does not expect to be called upon to pay before the ultimate date. He normally believes that an acceleration clause has been inserted in the evidence of his debt in order that the holder may be protected against his insolvency or similar contingencies, and he does not expect acceleration without good cause. The mere threat of such acceleration, if

1. Throughout the footnotes, the Code will be cited as UCC.

2. For a general discussion of the various innovations of the Code, see Beutel, Comparison of the Proposed Commercial Code, Article 3, and the Negotiable Instriments Law, 30 NEB. L. REv. 531 (1951); and Cosway, Innovations in Articles Three and Four of the Uniform Commercial Code, 16 LAw \& Conteamp. Pros. 284 (1951).

3. UCC \$3-109 (Official Draft, 1952). Unless otherwise specified, all sections and comments cited are those in the Official Draft.

4. There are of course objections which might crop up under other requirements for negotiability. UCC $\$ 3-104$ provides: “(1) Any writing to be a negotiable instrument within this Article must (a) be signed by the maker or drawer; and (b) contain an unconditional promise or order to pay a sum certain in money and no other promise, order, obligation or power given by the maker or drawer except as authorized by this Article; and (c) be payable on demand or at a definite term; and (d) be payable to order or to bearer."

5. Such a historical survey was taken in Note, Acceleration and Negotiability in Chattel Notes and Collateral Notes, 37 CoL. L. REv. 430 (1937). 
allowed, would prevent accurate planning as to future incidence of liabilities; and its actual occurrence could throw him into financial straits at a moment's notice. The maker is therefore worried about the avaricious creditor. On the other hand, the holder (creditor) is worried about the possibility that unforeseen future events may bring about the maker's default. Especially in periods of over-rapid business expansion and relative instability of money, a feeling of insecurity may be engendered by knowledge of facts that are hard to prove, or by confidential information, or even by mere suspicion. Therefore he does not wish to be bound to accelerate only upon stated contingencies. The resolution of these conflicts is not easy, and this is one area where the "uniform" NIL has not resulted in clarifying the law. The applicable provision reads:

"Section 4. An instrument is payable at a determinable future time ${ }^{6}$ . . . which is expressed to be payable,

"...

"(2) On or before a fixed or determinable future time specified therein...."

This section is sufficiently ambiguous to allow any result in acceleration cases. It has been suggested that no acceleration clauses should destroy negotiability under the NIL since a note containing one is surely payable "on or before a fixed . . . future time." 7 On the other hand, it is quite possible that $\S 4(2)$ was intended to provide only for the negotiability of notes payable before the fixed date at the option of the maker. Before the adoption of the NIL, it was held that a note payable "on or before" a certain date meant that only the maker had the option of payment before the date of maturity and that the holder could not sue before that time. ${ }^{8}$ Even after the NIL it was assumed that such was the rule. ${ }^{9}$ However, the overwhelming number of cases do not hold to either theory, as will be seen.

The requirement of certainty as to time of payment is dictated by practical business and legal considerations. Uncertain time leads to highly speculative money value of the paper, and increases both the danger of taking overdue paper, and the difficulty of making presentment and giving

6. This is one of the formal requirements of negotiability imposed by NIL $\S 1$.

7. See Britton, Bills and Notes 109-110 (1943); Beuter's Brannan, NegoTtABLE INSTRUMents LAW 276 (7th ed. 1948); National City Bank of Cleveland v. Erskine \& Sons, 158 Ohio St. 450, 463, 110 N.E.2d 598, 604 (1953) (concurring opinion citing Beutez's BranNaN, supra).

8. Moore v. Horsley, 42 Ark. 163 (1883); Mattison v. Marks, 31 Mich. 421 (1875) semble, but cited as standing for this proposition in Helmer v. Krolick, 36 Mich. 371, 372 (1877) ; Jordan v. Tate, 19 Ohio St. 586 (1869) semble.

9. See Lovenberg v. Henry, 104 Tex. 550, 140 S.W. 1079 (1911) (statute of limitations problem involving an "on or before" note, majority, concurring, and dissenting opinions all assume that payment could not be forced before maturity date); see Utah State National Bank v. Smith, 180 Cal. 1, 5, 179 Pac. 160, 161 (1919); cf. Union State Bank v. Benson, 38 N.D. 396, 165 N.W. 509 (1917). 
notice of dishonor at the right time. ${ }^{10}$ But, insofar as these considerations are concerned. acceleration paper does not differ from demand paper whose negotiability is expressly provided for. ${ }^{11}$ Furthermore, a note payable at a definite future time subject to acceleration is more certain than demand paper since it at least provides a definite time beyond which it cannot run. Yet various types of clauses incense courts enough to impose the sanction of non-negotiability on the notes, but not enough to declare the clauses unenforceable. ${ }^{12}$

\section{The Acceleration Clause in Practice}

Since the formal requirement of the NIL" is certainty of time, many attempts have been made to evolve a test whereby commercial practices could be fitted. into this requirement. The most famous of these is the suggestion by Professor Chafee that negotiability should not be destroyed by acceleration of maturity if the acceleration is possible "only by the performance of an act regularly incident to the collection of the paper." 13 The theory behind this suggestion is that the business world would consider paper readily salable only if it were unaffected by facts which are not stated on the instrument, or which cannot be ascertained during the normal business procedure in collection and payment. However, the types of clauses in use both then and now are considered to be for the protection of the holder, as will appear. This paper is therefore more suitable for circulation as a substitute for money than "clean" paper, ${ }^{14}$ i.e., promissory notes with no extraneous clauses in them. ${ }^{15}$

It is an interesting phenomenon that the banks, which would ordinarily be most vitally interested in problems of negotiability, are not concerned about the effect on negotiability of acceleration clauses. Various bankers in the city of Philadelphia, when interviewed, stated that they accept notes for discount only from their customers or from people whose credit is well known, in this way insuring themselves against the default of the maker. Regarded in this light, negotiability of a note is of no consequence since they will accept a non-negotiable note as collateral for a loan to their customer. The few notes containing acceleration clauses present no practical difficulty in the method of computing their value. Banks discount

10. For a critical analysis of these considerations in the light of business practices before 1920 , see Chafee, Acceleration Provisions in Time Paper, 32 Harv. L. REv. 747, 753-754 (1919).

11. NIL \&1(3).

12. The clauses will usually be enforced as written, subject to normal contract defenses. See, e.g., Messner v. Mallory, 107 Cal. App.2d 377, 236 P.2d 898 (1951). But cf. note 69 infra.

13. Chafee, supra note 10 , at 756 .

14. In Lincoln Nat. Bank v. Marsh, 24 N.Y.S.2d 281, 285 (Sup. Ct. 1940) it was said: "The value [of such paper] is certain and the danger of insolvency is to some extent overcome."

15. This type of note is a perfect example of Chief Justice Gibson's statement that "a negotiable bill or note is a courier without luggage." Overton v. Tyler, 3 Pa. 346, 347 (1846). 
the note at the amount it will produce at maturity and proceed against the negotiator if the note has to be accelerated and thus causes a loss to the bank. $^{16}$ Even all of this is largely theoretical since only a very small percentage of the paper offered to banks for discount contains acceleration clauses, and only a small number of these destroy negotiability.

The notes that banks have their borrowers sign are in a different category. They contain many clauses which are considered to be for the protection of the bank, although some of them destroy negotiability. But this is of no practical import, for rediscounting of notes with the Federal Reserve System has virtually stopped, ${ }^{17}$ because of a shift in the character of banks' assets. They now have a substantial amount of government bonds against which they can borrow. However, despite the lack of further negotiation, the bankers, remembering the 1930's, would still like to have their notes negotiable, so they try to keep out the negotiability-destroying clauses as much as possible.

Other groups which receive many promissory notes are the finance and small loan companies. With their high degree of credit risk they naturally have an assortment of acceleration clauses in their notes, but the notes are not discounted or negotiated to banks. If the lenders become hard-pressed for ready cash, they merely establish a line of credit with a bank on the basis of their accounts receivable. ${ }^{18}$

In the situations above described it is fair to say that acceleration clauses are not regarded commercially as a problem of negotiability, but rather as one of enforceability. It is platitudinous to state that the law should follow commercial practice, ${ }^{19}$ but this is perhaps the unexpressed major premise in this area. Dean Prosser, reporting for the American Law Institute, says: ${ }^{20}$ "It seems evident that the courts which give uncertainty of time of payment as a reason for denying negotiability are in reality objecting to the acceleration clause itself. This objection may be founded on abuses of the clause." And he further notes that "the effect of

16. So if a note were for $\$ 100$ plus $6 \%$ interest, payable one year after date, the amount discounted would be $\$ 106$ giving the negotiator $\$ 99.64$ if the discount rate is $6 \%$. If the note must be accelerated after 2 months, the bank would only collect $\$ 101$ from the maker, but would charge the negotiator's account with the $\$ 5.00$ lost.

17. An official of the Federal Reserve Bank of Philadelphia can recall only two or three rediscounting transactions at his bank in the last ten years. This situation is by no means localized. See Present Day BankIng 14 (1951): "With the general decline in recent years in the volume of commercial paper and bankers acceptances outstanding, discounting eligible paper is no longer an important means of securing funds to adjust the money positions of the metropolitan commercial banks."

18. This information is based on an interview, February 26, 1952, with Mr. Curtiss Williams, Executive Vice President of the Pennsylvania Consumer Finance Association which has approximately 500 individual loan companies as members.

19. See First Nat. Bank v. Skeen, 101 Mo. 683, 687, 14 S.W. 732, 733 (1890) : "The law governing such paper is the outgrowth of the usages of commerce. In determining disputed questions in its application it is often useful to recur to the objects and purposes of the law and to observe how far they may be promoted or defeated by the acceptance of any proposed construction of it."

20. UCC, Comments and Notes to Article III 43 (Tent. Draft No. 1, 1946). 
denying negotiability to acceleration paper is not to remedy any abuses arising in connection with the acceleration clause, which remains in effect even if the instrument be treated as a simple contract. It is merely to open the paper to defenses which have nothing to do with acceleration." This Note will attempt to see how the cases support the proposition that acceleration clauses are a problem of enforceability, not of negotiability.

\section{Acceleration Clauses Before the Courts}

The cases are so confused in their holdings and reasonings in this area that Professor Aigler was prompted to say: ${ }^{21}$ ". . . there is no test according to which a line may be drawn differentiating the holdings. The uncertainty in the law is pronounced and disconcerting." However, the holdings of the cases can be made to fit into the pattern of a theory never fully articulated by the courts, to wit: that the question of the negotiabilitydestroying character of any particular acceleration clause is ruled by principles analogous to those which control the doctrine of anticipatory repudiation of contracts. This latter doctrine, accepted by the vast majority of American jurisdictions, ${ }^{22}$ provides that a party to a bilateral contract commits a breach by any voluntary affirmative act (before a failure to perform at the time stated) which renders substantial performance of his contractual duties impossible, or apparently impossible. ${ }^{23}$ A promissory note is a unilateral contract if it is a contract at all, ${ }^{24}$ and therefore the doctrine cannot be literally applied. But the principle that it reflects fits just as well into the field of commercial paper, i.e., that one need not wait to sue until the final time for performance if it is clear that substantial performance will not occur. ${ }^{25}$ This principle has been partially recognized by NIL $\S 2(3)$, which would allow a term that "upon default in payment of any instalment or of interest, the whole shall become due." 26

Naturally, in the field of credit extension, where knowledge of shaky financial condition often comes from confidential sources, the manifestation need not be by an affirmative act of the maker in all cases. With this in (1929).

21. Aigler, Time Certainty in Negotiable Paper, 77 U. of PA. L. REv. 313, 322

22. See 4 Corbin, Contracts $\$ 959$ (1951); Williston, Contracts $\$ 1337$ (Rev. ed. 1937).

23. Restatearent, Contracts $\$ 318$ (Supp. 1948).

24. "A negotiable instrument is a written promise, or order to pay to the order of a named payee, or to bearer, a specified sum of money. It is on its face unilateral and unconditional." 4 CORBrN, CoNTracts $\$ 863$ (1951).

25. See Gardner, Inquiry Into the Principles of the Law of Contracts, 46 Harv. I. REv. 1, 14 (1932): "Anticipatory breaches' differ from 'actual' breaches only in the fact that the non-existence of the predicted power is made manifest before the date for performance, and in some other manner than by the unsuccessful effort to put the predicted power into practical effect."

26. Such a term only results in the sum payable being a sum certain by that section. However, such a clause must surely not destroy negotiability for the draftsmen would not have given a defective example. Such have been the holdings. See note 29 infra. These clauses are also enforceable as written. See, e.g., Harris v. Kessler, 124 Cal. App. 299, 12 P.2d 467 (1932). 
mind it is possible to state the proposed rationalization of the cases: when a note contains clauses which accelerate maturity upon the occurrence of facts which manifest an inability or unwillingness to pay on the part of the maker, the note will be given full effect; but when the accelerating facts do not manifest such an inability, the note will be declared non-negotiable. Such a penalty might possibly be justified on the ground that the maker trusted that his original creditor would not invoke the clause without good reason. ${ }^{27}$ No trust was placed in anyone else; ${ }^{28}$ therefore, to protect the maker the court, by holding the note non-negotiable, allows him to interpose personal defenses even against one who would otherwise be a holder in due course. This of course is harsh on the holder, but it is merely another example of courts policing commercial practices. A holding of nonnegotiability was thought to have a strong deterrent effect on the use of the clauses originally, and perhaps historically it did, in the era when negotiation was more frequent than today.

Thirty-seven notes used by banks and loan companies were analyzed and found to contain twenty-one different types of acceleration clauses. The cases dealing with these clauses are grouped below according to the type of factual situation the clauses describe, in an effort to place the cases into the rationalization stated above.

Default by the Maker.-Thirty-two clauses were found which accelerated "if default shall be made in the payment of any of said installments, or sums on this note, or any renewal thereof." Such notes are plainly not certain as to time or amount in vacuo, but there is unanimity in holding that these clauses do not destroy negotiability. ${ }^{29}$ The same also applies where a series of notes is matured on default in the payment of any one note. $^{30}$ These accelerating facts show an inability or unwillingness on the part of the maker to pay his obligations when due, ${ }^{\mathbf{3 1}}$ and the holdings of

27. Especially is this trust important when the clause allows acceleration "when the holder deems himself insecure." Such a clause is seldom used today.

28. It is arguable that the maker realized the note would be negotiated. This however seems specious in light of the business facts of life discussed above. In other areas of commercial dealings, such as installment retail buying, negotiation is contemplated but most of these notes have on them the name of the ultimate payee and it is in his discretion that the trust is actually placed.

29. E.g., Dorbecker v. Downey Co., 88 Ind. App. 557, 163 N.E. 535 (1928); Illinois Bankers Life Assurance Co. v. Day, 178 Okla. 284, 62 P.2d 970 (1936); International Finance Co. v. Magilansky, 105 Pa. Super. 309, 161 Atl. 613 (1932)'. See also note 26 supra.

30. E.g., Farmers' Bank \& Trust Co. v. Dent, 206 Ky. 405, 267 S.W. 202 (1924) ; Rees, Taylor Co. v. Mayflower Diners, 110 N.J.L. 437, 166 At1. 96 (1933); Koppler v. Bugge, 168 Wash. 182, 11 P.2d 236 (1932).

31. This is true as a general proposition. But of course there may always be exceptions. So in Canton Hardware Co. v. Haller, 142 Ohio St. 541, 53 N.E.2d 509 (1944), the maker refused to pay an installment because he had a claim for breach of warranty against the payee. The court indicated that the maker would not be in default if the jury found the damages for the breach to be greater than the amount of the installments due at the time of suit. Here, however, the jury found for the maker but in an amount less than the matured installments. The court therefore allowed acceleration.

In Collins v. Collins Estate, Inc., 207 S.C. 452, 36 S.E.2d 584 (1946), the maker of an installment-default-acceleration note died before time for payment of a crucial 
negotiability are perfectly consistent with the principles of the anticipatory repudiation doctrine. Also conforming to these principles is the type of clause found in eleven notes that "failure to perform any agreement hereunder" matures the note, and this clause has been held not to impair negotiability. ${ }^{32}$

Facts Indicating an Inability or Unwillingness to Pay.-Thirty notes contained a clause accelerating the time of payment on "the death of any maker;" four included "dissolution of any corporate maker ;" 32 matured upon "the insolvency of the maker" and "the committing of an act of Bankruptcy or the filing of a petition under any of the provisions of the National Bankruptcy Act;" and 22 notes accelerated upon "the appointment of a receiver for maker.". All of these occurrences manifest to the creditor the high probability that the maker will be unable to perform his obligations. This type of acceleration is particularly important to the holder since it allows him to get into the race of the creditors which is likely to develop on the happening of the above contingencies. In the reported cases, notes containing all or a combination of these clauses have been held negotiable. ${ }^{83}$ Some notes have had only the insolvency provision and they also were held negotiable. ${ }^{34}$ Along the same line as these clauses is one accelerating upon "the making of an assignment for the benefit of creditors." This provision was in 29 notes and should be governed by the same principles as above since this is merely another Act of Bankruptcy..$^{35}$

Where loans are made on the faith of a going business, it is only natural to assume there will be acceleration upon the failure of the business.

installment, leaving his wife as executrix of his estate. She felt that she might not be able to make the payments exactly on time because of troubles in the administration of the estate. Since she did not want the holder to sell the stock pledged, she brought suit for an injunction pendente lite before the time set for payment. The injunction was granted, seemingly on the theory that the court had the necessary power to grant a permanent injunction against acceleration. Implicit in this holding might be the fear that the maker's estate could be excessively depleted by having its stock sold for a song just because of a failure to pay on time. This failure might be due to difficulties in administration and not to an inability to pay. In fact, this case seemed to involve a solvent decedent.

32. E.g., Commerce Trust Co. v. Guarantee Title Co., 113 Kan. 311, 214 Pac, 610 (1923); Davis v. Union Planters Nat. Bank \& Trust Co., 171 Tenn. 383, 103 S.W.2d 579 (1937) (these cases involved clauses in the note accelerating on failure to comply with any condition in a mortgage which secured the note); Manlius First Nat. Bank v. Garland, 160 I11. App. 407 (1911). Contra: Central Savings Bank v. Coulter, 72 Cal. App. 78, 236 Pac. 956 (1925) (acceleration on breach of covenants as to payments of interest, taxes, etc. destroys negotiability under NIL $\$ 4$ because it is payable on a "contingency").

33. E.g., Shawano Finance Corp. v. Julius, 214 Wis. 637, 254 N.W. 355 (1934); Cook v. Parks, 46 Ga. App. 749, 169 S.E. 208 (1933); Bonart v. Rabito, 141 La. 970, 76 So. 166 (1917).

34. E.g., Chelsea Exch. Bank v. Warner, 118 Misc. 159, 195 N.Y. Supp. 419 (Sup. Ct. 1922); Wright v. Seaboard Steel \& Manganese Corp., 272 Fed. 807 (2d Cir. 1921) semble. But cf. Great Falls Nat. Bank v. Young, 67 Mont. 328, 215 Pac. 651 (1923). Bui sce Anderson v. Border, 87 Mont. 4, 10, 285 Pac. 174, 176 (1930).

35. 30 STAт. 546 (1898), as amended, 11 U.S.C. $\$ 21$ (a) (4) (1952). A note containing such a clause is enforceable as written. Gaston v. Boston Penny Sav. Bank, 233 Mass. 23, 123 N.E. 101 (1919). 
One of the notes analyzed so provided. Four others accelerated upon "suspension of business." Clauses relating to failure of the maker do not destroy negotiability, ${ }^{36}$ and are thus in accord with the rationalization attempted. So also is a clause reading ". . . if any maker shall . . . secrete or dispose of his or her property with intent to hinder, delay, or defraud his or her creditors," 37 or "if any maker shall abscond or remove from the jurisdiction." These clauses, appearing in two notes, show the holder that he will meet with difficulty in enforcing payment if these facts occur. No cases have been found interpreting these clauses, ${ }^{38}$ but there is every reason to believe they would be held not to destroy negotiability. They fit the anticipatory repudiation theory and also the language of the time certainty requirements espoused by the courts. ${ }^{39}$

In none of the situations described in this section is there a need to protect the maker against the exercise of the accelerating right by someone other than the original creditor, since a decision to accelerate on these facts cannot be considered to be unreasonable or unfair.

Facts Not Necessarily Implying an Inability to Pay.-Some clauses describe factual situations which only give rise to an inference of a pending inability to pay. The stronger the inference the more likely it is that the note will be held negotiable.

Such a strong inference arises from a clause maturing a note upon "the entry of a judgment against any maker." This clause appeared 13 times, and was qualified in five instances by "which is not satisfied within 10 days." Twenty-two other notes were matured upon "the issuance of an attachment against any maker." The occurrence of these facts suggests an inability on the part of the maker to pay his debts ${ }^{40}$ and it could not be

36. Dart Nat. Bank v. Burton, 258 Mich. 283, 241 N.W. 858 (1932); West Point Banking Co. v. Gaunt, 150 Tenn. 74, 262 S.W. 38 (1924). Also, the same result was reached where the clause accelerated on "disposing of business." McCornick \& Co. v. Gem State Oil Co., 38 Idaho 470, 222 Pac. 286 (1923).

37. This is also an Act of Bankruptcy. See 30 Stat. 546 (1898), as amended, 11 U.S.C. $\$ 21$ (a) (1) (1952).

38. There are cases on a closely analogous clause, to wit: "if [the property given as consideration for the note] is levied upon or maker attempts to sell or remove same," then acceleration is allowed. These clauses of course should not destroy negotiability since they fit the theory propounded, and it has been so held. Abingdon Bank \& Trust Co. v. Shiplett-Moloney Co., 316 Ill. App. 79, 43 N.E.2d 857 (1942) ; Schmidt v. Pegg, 172 Mich. 159, 137 N.W. 524 (1912). The clauses discussed in the text are not limited to removing any specific property, but these cases are persuasive for the same result here.

39. See McCornick \& Co. v. Gem State Oil Co., 38 Idaho 470, 480, 222 Pac. 286, 290 (1923) : "[acceleration clauses do not destroy negotiability if] none of the conditions in the acceleration clause depend upon any act of the holder, nor are they within his control, but all of such contingencies depend either upon some act or omission of the maker, or upon an event indicated in the paper not within the control of either party." See also Aigler, supra note 21, at 326.

40. This is not necessarily true if the attachment is the normal foreign attachment necessary to start suit against a non-resident. Bank officials today consider that type of attachment sufficient to accelerate. If a court felt strongly about the harshness of this provision, they could destroy its negotiability by the same reasoning as in note 44 infra. 
considered an abuse of discretion for the holder to mature his note earlier to guard against an inability to pay that debt also. Notes containing such clauses accordingly have been held negotiable. ${ }^{41}$ This result is easily justified where the note is in the hands of a distant holder, who should be able to act on less evidence to get into the race of the creditors than the immediate payee.

Today, applications for loans precede most grants and are relied upon by the lenders to a great extent. If a false credit picture is painted, the inference is strong that the loan would not have been granted but for the misrepresentation. If these facts later come to light, the lender would want to accelerate. Seven clauses were found which allowed acceleration upon "any statements . . . which are the inducement for this loan, proving to the satisfaction of the holder hereof to be untrue." In the only case found on point, ${ }^{42}$ negotiability was not destroyed by a clause reading "should any representation herein made be found untrue." The only difference between the clauses is that the one in use today seems to let the date of maturity rest on the "satisfaction of the holder." At first blush, it would seem that trust is placed in the discretion of the creditor, but actually no maker could in good conscience expect leniency after a falsehood in procuring the loan. The problem of the unscrupulous creditor in this situation is more apparent than real. If he wishes to accelerate, the jury must still find that the statements were false to his satisfaction, and it is unlikely that they would so find unless the evidence brought forward by the holder could reasonably sustain the inference of falsity. The principles of the anticipatory repudiation doctrine appropriate for commercial paper are thus satisfied and there is high probability that the courts would hold that the present-day clause does not destroy negotiability, since the reason for denying negotiability in the case of an uncontrolled power in the holder is the feeling that such power would give him an unfair advantage over the maker. ${ }^{43}$ Here the maker has already taken advantage of the lender and he does not need that protection.

Other clauses describe factual situations which give rise to very weak inferences of inability to pay. Such a clause is one that matures the note if "any legal or equitable proceedings are instituted against . . . any of the undersigned." This was found in five notes. Clearly such an occurrence does not evince an inability to pay since the suit may be wholly unfounded or instituted in collusion with the holder, and within the rationalization of this Note this clause should be held to destroy negotiability. One such holding is reported under the NIL.44 Another type of such clause

41. Glide v. Sheridan, 173 Misc. 542, 18 N.Y.S.2d 339 (Sup. Ct. 1939).

42. Cook v. Parks, 46 Ga. App. 749, 169 S.E. 208 (1933).

43. See Palmer, Negotiable Instruments Under the Uniform Comnercial Code, 48 Mich. L. Rev. 255, 263 (1950).

44. Great Falls Nat. Bank v. Young, 67 Mont. 328, 215 Pac. 651 (1923). The court noted that: "Also, the maker or an indorser, may be sued the next day after the note is given, or the next week, upon a claim without any foundation, and over which event neither the maker nor indorser would have any control, and the note may be declared to be due and payable. . . ." Id. at 336, 215 Pac. at 653. 
was found in six notes, accelerating upon "the taking of possession or control of any substantial part of the property or business of any obligor by or at the instance of any governmental or public authority." The commercial lending institutions contemplate by this provision an attachment under a tax lien or an attachment of contraband property. These events do not necessarily mean that the maker's financial condition is bad and notes containing such clauses should be non-negotiable. ${ }^{45}$

A borderline clause is one by which the maker can be forced to pay before the ultimate date if he "suffers a fire loss." This clause was found in only one promissory note in use today, but it has been twice held negotiable in the past. ${ }^{46}$ Despite the fact that under such a clause a fire in the woodshed is an accelerable event, these holdings can possibly be rationalized on the ground that this clause was only found in combination with other clauses relating to the business operations of the maker ${ }^{47}$ and therefore the doctrine of ejusdem generis would limit the construction of this clause to fire loss affecting the business.

Subjective Insecurity.-Insecurity is the usual state of mind accompanying a demand by the holder before maturity, and it is only natural to find some clauses accelerating on the advent of that feeling. Four clauses were found which accelerated "if the financial condition of the undersigned shall so change as, in the judgment of the holder, to materially increase its risks hereunder;" and five clauses read "any material adverse change in the financial condition of any obligor." Clearly discretion is given the lender as to when to accelerate, and there seems to be no criterion which a jury could apply to determine whether he actually did feel insecure. The mere feeling of insecurity does not indicate a manifestation of a pending inability to pay, and this clause should be held to destroy negotiability. Such has been the almost unanimous holding.8 The reason given by the courts here is that "the date of maturity is placed wholly under the control of the holder, is completely dependent upon his whim or caprice, and is

45. It is possible that this clause describes a typical eminent domain case. If anything, such a situation would indicate a fairly strong ability to pay since the owner of the property would recover its fair value from the government exercising the power of eminent domain. This payment would be in cash and his assets would then be liquid instead of tied up in his business. The theory of this Note would then dictate non-negotiability for this clause, but no cases have been found on point.

46. Peoples Finance \& Thrift Co. v. Shaw-Leahy Co., 214 Cal. 108, 3 P.2d 1012 (1931); McCornick \& Co. v. Gem State Oil Co., 38 Idaho 470, 222 Pac. 286 (1923).

47. The note in use today also accelerated on default in payment of interest or principal, refusal to furnish additional collateral on demand, failure in business, insolvency, bankruptcy or death of the maker. The instruments in the cases in note 46 supra were identical with each other and accelerated also upon suspension of payment, giving a chattel mortgage, disposing of the business, and failing to pay any prior trade acceptance.

48. E.g., Murrell v. Exchange Bank, 168 Ark. 645, 271 S.W. 21 (1925); Holliday State Bank v. Hoffman, 85 Kan. 71, 116 Pac. 239 (1911); Guio v. Lutes, 97 Ind. App. 157, 184 N.E. 416 (1933) ; Harrison v. Fugatt, 179 Okla. 367, 65 P.2d 1200 (1937); Puget Sound State Bank v. Washington Paving Co., 94 Wash. 504, 162 Pac. 870 (1917). Contra: Dart Nat. Bank v. Burton, 258 Mich. 283, 241 N.W. 858 (1932). 
independent of any act done or omitted by the maker." 49 This language clearly accords with the proposition that acceleration clauses are problems of enforceability, ${ }^{50}$ and the few cases which hold these clauses negotiable recognize this and say that the certainty of time requirements are met. ${ }^{51}$ However, the language of the majority of the cases fits within the basic theory of this Note, and the holdings fit the attempted rationalization.

Default in Failing to Provide Additional Collateral.-The tendency among lenders is to give unsecured loans to good credit risks. However, if the credit is slightly shaky, collateral will be demanded on a $15-30 \%$ margin depending on the commodity pledged.52 It is only natural that if the value of the collateral falls the lender will wish the borrower to furnish more. Thirteen of the notes examined accelerated "if the undersigned shall not on demand furnish such further collateral . . . as shall be satisfactory to the holder," and nine required that the maker "within two hours after demand deposit with holder such additional security as shall be satisfactory to the latter." A failure to make up the depreciation in value ${ }^{53}$ indicates clearly a pending inability to pay, and these clauses have been held not to destroy negotiability. ${ }^{54}$ The only difficulty with these holdings is that the "satisfaction of the holder" smacks of subjective in-

49. See Nickell v. Bradshaw, 94 Ore. 581, 597, 183 Pac. 12, 18 (1919).

50. See text after note 20 supra.

51. In Lincoln Nat. Bank v. Marsh, 24 N.Y.S.2d 281 (Sup. Ct. 1940), it was said: ". . . there is no logical basis for distinguishing between an acceleration clause which becomes operative when the holder determines that the maker's financial affairs increase the holder's risk and a clause which becomes operative in the event of death, insolvency or bankruptcy of the maker. . . To hold that an instrument payable at a fixed time but accelerable at the option of the holder destroys its negotiability seems to me to be directly contrary to the plain meaning of [NIL \$ 4(2)]." Id. at 285 .

An interesting case is National City Bank of Cleveland v. Erskine \& Sons, 158 Ohio St. 450, 110 N.E.2d 598 (1953). A chattel mortgage had been given and the accompanying note accelerated "in the event that the chattel mortgage securing this note is breached in any respect." The mortgage allowed the mortgagee to declare the whole sum due if he for any reason deemed the indebtedness insecure. The court held the note negotiable on the theory that the insecurity clause was not incorporated into the note, since the word "breach" could only apply to the affirmative covenants of the maker. This seems to be an obvious straining to reach a result. One concurring opinion felt that the insecurity clause was available only to the mortgagee and not to a subsequent holder. The other concurrence was based on the theory that the note would be negotiable even if the insecurity clause were incorporated into it. See note 7 supra, and accompanying text. The dissenting judge felt that the clause was incorporated and therefore the note was non-negotiable.

52. For example, a leading bank in Philadelphia will lend about $70 \%$ of the value of marketable securities, up to $80 \%$ on Warehouse Receipts (depending on the commodity-staples bring more), up to $85 \%$ on Trust Receipts, and up to $100 \%$ on savings accounts or the cash surrender value of life insurance policies.

53. Today such additional collateral is not called for until the margin drops to below $5-10 \%$.

54. E.g., First Nat. Bank v. Stoneley, 111 N.J.L. 519, 168 Atl. 602 (1933) ; Mechanics \& Metals Nat. Bank v. Warner, 145 La. 1022, 83 So. 228 (1919) ; Empire Nat. Bank v. High Grade Oil Refining Co., $260 \mathrm{~Pa}$. 255, 103 Atl. 602 (1918); West Point Banking Co. v. Gaunt, 150 Tenn. 74, 262 S.W. 38 (1924) ; cf. Sommers v. Goulden, 147 Okla. 51, 294 Pac. 175 (1930). Contra: First Nat. Bank v. McCartan, 206 Iowa 1036, 220 N.W. 364 (1928); American Finance Co. v. Bourne, 190 Okla. 332,123 P.2d 671 (1942). 
security. This obstacle is easily overcome if a requirement is imposed that the seller's satisfaction or lack of it must be based upon reason and must not be arbitrary or capricious. ${ }^{55}$

Some courts have seized upon $\S 5$ of the NIL to declare these notes non-negotiable. ${ }^{56}$ That section provides: "An instrument which contains an order or promise to do any act in addition to the payment of money is not negotiable." However, no unconditional additional promise is made, since the additional-collateral clause is always coupled with an acceleration clause, and the maker always has the alternative of defaulting. It therefore has been suggested that $\S 5$ is not a proper tool to use in declaring such a note non-negotiable. ${ }^{57}$

Summary.-The cases, when analyzed according to the factual situations described, establish the proposition that the power to accelerate will not destroy negotiability if it is conditioned upon the occurrence of some act or event, objectively manifested, and of such a nature as to indicate a probability that payment will not be made at the date of ultimate maturity. But a clause allowing acceleration upon the happening of a condition which cannot be established by objective evidence indicating an inability to pay will destroy negotiability. This tends to show that the underlying theory behind the imposition of the sanction of non-negotiability is one analogous to the anticipatory repudiation doctrine of contract law. The doctrine itself has been held to be inapplicable in cases involving premature suits on promissory notes without acceleration clauses. ${ }^{58}$ But this does not mean that the principles cannot govern express provisions in the paper. There are of course other types of clauses not much in evidence at present. These clauses do not fit into any of the above categories but describe situations in which acceleration is provided for if the maker is able to pay sooner than he expected. Such a clause might force earlier payment if the maker "shall be able to collect a certain note against X." The maker needs no protection here, the facts are easily ascertainable, and this clause has been held negotiable. ${ }^{59}$

55. This requirement was implicitly adopted in a sales contract situation in James B. Berry's Sons Co. v. Monark Gasoline \& Oil Co., 32 F.2d 74 (8th Cir. 1929). See also Harris v. Thomas, 17 Ala. App. 634, 88 So. 51 (1921) (same requirement in a mortgage situation).

56. E.g., Holliday State Bank v. Hoffman, 85 Kan. 71, 116 Pac. 239 (1911) ; Nussear v. Hazard, 148 Md. 345, 129 At1. 506 (1925).

57. Chafee, supra note 10, at 783: "The question in every case is not whether the act is technically 'additional' to the payment of money, but whether it is substantially so. If its real purpose is to aid the holder to secure the payment of money and protect him from the risks of insolvency, if it steadies the value of the note, and makes it circulate more readily, then it should not be fatal to negotiability." Also see Finley v. Smith, $165 \mathrm{Ky} .445,453,177$ S.W. 262, 266 (1915).

58. Upham v. Shattuck. 151 Kan. 966, 101 P.2d 901 (1940) ; Huffman v. Martin, $226 \mathrm{Ky} .137,10$ S.W.2d 636 (1928).

59. McCarty v. Howell, 24 I11. 341 (1860) ; accord, Walker v. Woollen, 54 Ind. 164 (1876) ; Charlton v. Reed, 61 Iowa 166, 16 N.W. 64 (1883) ; Ernst v. Steckman, $74 \mathrm{~Pa} .13$ (1873). Cf. State Bank of Halstad v. Bilstad, 162 Iowa 433, 136 N.W. 204 (1912). 


\section{Acceleration Clauses Under the Commercial Code}

The draftsmen of the Code recognized that the problem in acceleration clauses was one of enforceability, not of negotiability, ${ }^{60}$ and therefore provided that no such clause destroys negotiability by reason of lack of definiteness in time. ${ }^{61}$ Further, they inserted a special section to take care of those jurisdictions which destroyed the negotiability of a clause which accelerated on default in providing further collateral on the theory that it was a promise to do an act in addition to the payment of money. ${ }^{62}$ The Code's provision reads:

"(1) The negotiability of an instrument is not affected by “...

"(c) a promise to give additional collateral on demand. . . ." 63

Having thus closed all the loopholes, the Code makes it impossible for an acceleration clause to destroy negotiability.

The answer to the enforceability problem is to be found in Section 1-208, which reads:

"A term providing that one party may accelerate payment or performance or require collateral or additional collateral not on stated contingencies but 'at will' or 'when he deems himself insecure' or in words of similar import means that he has power to do so only in the good faith belief that the prospect of payment or performance is impaired but the burden of establishing the lack of good faith is on the party against whom the power has been exercised."

This is couched in the language of anticipatory repudiation. In fact the comment to an earlier draft says: "The basic purpose of such clauses is recognized and given effect in the Sales Article (Article 2)...." Section 2-609 gives one party to a sales contract the right to demand adequate assurance if he has reasonable grounds for insecurity, and if such assurance is not given, a breach by repudiation occurs. ${ }^{65}$ The Code there-

60. See text at note 20 supra. See also UCC $\$ 3-109$, comment 4: "So far as certainty of time of payment is concerned a note payable at a definite time but subject to acceleration is no less certain than a note payable on demand, whose negotiability never has been questioned. It is in fact more certain, since it at least states a definite time beyond which the instrument cannot run. Objections to the acceleration clause must be based rather on the possibility of abuse by the holder, which has nothing to do with negotiability and is not limited to negotiable instruments."

61. UCC $\$ 3-109:$ :(1) An instrument is payable at a definite time if by its terms it is payable

“...

"(c) at a definite time subject to any acceleration. . . ."

62. See note 56 supra.

63. UCC § 3-112.

64. UCC \$1-208, comment (Proposed Final Draft, Spring 1950).

65. UCC $\$ 2-609(4)$. Section 2-610 lists the courses of action available to the party aggrieved by such repudiation and section 2-611 allows a retraction of the repudiation before the time set for performance, but only if the aggrieved party has materially changed his position. 
fore recognizes that the principles of the doctrine apply to acceleration clauses, ${ }^{66}$ but unfortunately only to those clauses which allow acceleration "'at will' or 'when he deems himself insecure' or in words of similar import." This means that acceleration will be allowed on other contingencies even though they have little or no connection with the ability of the obligor to pay. This seems to go against the policy of protecting the debtor from ruin due to a premature calling by an unscrupulous creditor, ${ }^{07}$ especially where the contingencies are so numerous that they are likely to occur, or where they are in the control of the holder. However, this undesirable result may be circumvented within the framework of the common law. There are mortgage cases holding that a court of equity has power to relieve against an acceleration clause where the facts indicate that the mortgagee's conduct is inequitable. ${ }^{68}$ The court can also restrain the invoking of the clause where no future inability to pay is shown, ${ }^{69}$ or where the mortgagor defaulted by mistake and a foreclosure would work undue hardship on him. ${ }^{70}$ There is no reason why these principles could not be carried over from the mortgage field into an action to restrain the premature calling of a promissory note. ${ }^{71}$ Therefore, it would seem better to

66. See UCC $\$ 2-609$, comment 2: “. . . this section provides' the means by which the aggrieved party may treat the contract as broken if his reasonable grounds for insecurity are not cleared up within a reasonable time. This is the principle underlying the law of anticipatory breach, whether by way of defective part performance or by repudiation."

67. See note 44 supra.

68. Loughery v. Catalano, 117 Misc. 393, 191 N.Y. Supp. 436 (Sup. Ct. 1921). In this case the mortgagee could accelerate if the mortgagor made any alterations without first obtaining the mortgagee's consent. Alterations were made but the court dismissed a foreclosure action because the alterations did not change the character of the building or the use to which it was put, were not substantial in character and did not injure the mortgagee or impair the security. See Graf v. Hope Bldg. Corp., 254 N.Y. 1, 7, 171 N.E. 884, 886 (1930) (dissenting opinion by Cardozo, C.J.). See generally, Note, 88 U. of PA. L. REv. 94 (1939).

69. Woodward v. Elrod, 154 Ala 340, 45 So. 647 (1908). Here the clause accelerated if the mortgagor transferred or removed any property, including the crops, from the land mortgaged to secure the debt. He did so remove and sell some of the crops, but the court restrained the foreclosure of the mortgage on the ground that the intent of the parties was that the mortgage could be paid in cash and all the installments had been paid when due and there was no reason to believe that they would not be paid when due in the future.

Also see Uniform Real Estate Mortgage Act, \$10, Handbook, Nat. Conf. Comm'rs UNIF. STate Laws 679 (1927): "Where the principal of a mortgage, or any part thereof, has become due by reason of an acceleration clause, payment or tender before sale on foreclosure, of the amount, other than such principal, due and in default under the mortgage, with costs of foreclosure including attorney's fees incurred up to the time of payment or tender, shall relieve from the default whereby the principal became due, and shall reinstate the terms of the mortgage; and the foreclosure for such principal shall cease." The comment to this section states: "The section provides the mortgagor with protection against the right to declare the whole of a large mortgage due on a default of a few days in an installment. To replace the mortgage would require another commission, and there is hardship on the mortgagor in exposing him to the payment of a large commission because of a slight default." This Act was withdrawn by the Commissioners in 1943. See HandBook, Nat. Conf. Comm'rs Unif. State Laws 66, 307 (1943).

70. Petterson v. Weinstock, 106 Conn. 436, 138 At1. 433 (1927).

71. In a recent case, this principle came close to being adopted in the promissory note area. Bischoff v. Rearick, 232 S.W.2d 174 (Tex. Civ. App. 1950), in- 
have set forth this principle in section 1-208 and thus make it apply to all acceleration clauses. $^{72}$

There is another problem raised by section 1-208. If a holder attempts to accelerate in bad faith, will he be barred from accelerating later? Some courts might not allow further acceleration since they would like to prevent unnecessary harassing of debtors. However, it would seem preferable to allow a second attempt rather than leave a creditor in an insecure position where there actually is a strong likelihood of inability to pay.

Problems of the Holder in Due Course.-A variation of the problem of further acceleration occurs when a creditor who has made an ineffectual attempt to accelerate negotiates the note to another person. If the purchaser has reasonable grounds to believe that acceleration has been made he has notice that the instrument is overdue ${ }^{73}$ and is therefore not a holder in due course. ${ }^{74}$ But if the purchaser only knows that acceleration has been attempted, the question would once again arise as to whether he may later attempt to accelerate. ${ }^{75}$ Here a split could also be predicted, but more weight should be given to the problems of the holder since the punishment for harassing a debtor should not be inflicted on a person suing for the first time.

The other major problem facing a prospective holder in due course is the effect on his status of a clause providing that on the happening of the accelerative events "the principal sum shall become due and payable immediately." This so-called automatic-acceleration clause was found in

volved a series of late payments. One maker was on duty in Japan. He left money with the other maker who sent a check to the payee every month thinking he was on time. After the date for one particular payment had passed, payee immediately notified makers of his exercise of option to accelerate. The makers made immediate tender and kept the tender open. The lower court found that the holder was interested mainly in accelerating the debt, and not in getting his installments as they fell due. (The evidence also tended to show that there was no danger of his not being paid in the future.) The petition to accelerate was denied and this was affirmed on appeal. The court noted that equity could relieve against acceleration when it is caused by the inequitable conduct of the creditor himself, and imposed the requirement that the holder first make a demand before declaring the whole sum due.

72. This may be the result under the Code anyway. \$1-203 states: "Every contract within this Act imposes an obligation of good faith in its performance or enforcement." The comment to this section notes that this is a general principle of the Code and that particular applications of the principle appear scattered throughout (citing, inter alia, $\$ 1-208$ ). The draftsmen then seemingly annihilate the restrictions in $\S 1-20 \$$ by saying: "The concept, however, is broader than any of these illustrations and applies generally, as stated in this section, to the performance or enforcement of every contract within this Act." A negotiable instrument can be considered a contract under $\$ 1-201$ (11): "Contract' means the total obligation in law which results from the parties' agreement as affected by this Act, and any other applicable rules of law."

73. UCC \& 3-304(4) (c).

74. UCC \$3-302(1) (c).

75. Under an earlier draft, the purchaser would not have been a holder in due course if he had reasonable grounds to believe that "acceleration of the instrument has been made or attempted." UCC \$ 3-304 (4) (c) (Proposed Final Draft, Spring 1950). As one not a holder in due course, he is subject to all defenses which would be available in an action on a simple contract. UCC \$3-306(b). This would then depend on what stand the court took with regard to further acceleration by the original creditor. 
20 of the notes in use today. Under the NIL, the courts were fairly evenly split on whether the occurrence of the named events actually did mature the note and make it overdue so that a subsequent holder could not be one in due course. ${ }^{76}$ Unfortunately, it appears that the Code does not resolve this conflict. If the purchaser has reasonable grounds to believe that acceleration has been made, he cannot be a holder in due course. Does the fact that the note contains an automatic acceleration clause put him on notice that it might be overdue? The states holding that such a clause matures the instrument could easily hold that the purchaser has sufficient notice to be placed on his guard at that time, since the clause is in the note. ${ }^{77}$ It would seem that the better construction is that proposed by Professor Chafee: "The ultimate time of payment is the maturity of the instrument for all purposes with respect to persons who have not received notice that the fact which was to accelerate payment has occurred." 78

Notwithstanding the resolution of the above conflict, a holder of a note with an automatic acceleration clause in it is excused from delay in presentment or notice of dishonor or protest (where the clause operates to mature the note automatically) when he is without knowledge that it is due. ${ }^{79}$

Burden of Proof.-The Code puts the burden of establishing the holder's lack of good faith on the maker. This burden is defined as "the burden of persuading the triers of fact that the existence of the fact is more probable than its non-existence." 80 This means that the holder need not introduce evidence of good faith to get to the jury unless the rare case occurs where the quantum of the maker's evidence is so great that the court will direct a verdict in his favor. If the maker's evidence is less than that, the holder could take the chance that the jury would not be persuaded by it. The "good faith" in issue means "honesty in fact in the conduct or transaction concerned." $\$ 1$ It seems fair that the maker be the one to carry this burden, since creditors frequently must act on the basis of confidential information or evidence which does not amount to definite proof. Makers should not be allowed to take advantage of the technical rules of evidence to hinder collection attempts unless they can show a lack of good faith. In certain instances it may be to the maker's best interests to keep secret the information which led to the holder's insecure feeling. ${ }^{22}$ The Code leaves

76. See cases collected in 159 A.L.R. 1078 et seq. (1945).

77. See Wulfekuhler State Bank v. Wible, 121 Kan. 66, 245 Pac. 1067 (1926). This has also been done in a statute of limitations problem. Barnwell v. Hanson, $80 \mathrm{Ga}$. App. 738, 57 S.E.2d 348 (1950), held that the statute starts running immediately upon the maker's failure to pay an interest installment where the note is accelerated automatically. The theory of the court was that the purchaser saw the clause in the note and should have investigated.

78. Chafee, supra note 10 , at 757 .

79. UCC \$3-511(1). Comment 2 to this section specifically negates, in this situation, the split envisaged above. It notes that: "This [excuse for delay] is true where an instrument has been accelerated without his [holder's] knowledge. $80 . \dot{U} \dot{\text { UCC }} \$ 1-201$ (8).

81. UCC \$1-201(19).

82. Such might be the case if the feeling is due to the maker's indiscreet chuice of companions or misfortune at the gaming tables. 